\title{
THE RELATIVE EFFICIENCY OF EDUCATION AND R\&D EXPENDITURES IN THE NEW EU MEMBER STATES
}

\author{
Aleksander Aristovnik \\ Faculty of Administration, University of Ljubljana, Slovenia \\ E-mail: aleksander.aristovnik@fu.uni-lj.si
}

Received 30 April 2011; accepted 11 August 2011

\begin{abstract}
The paper attempts to measure relative efficiency in utilizing public education and R\&D expenditures in the new EU member states in comparison to the selected EU (plus Croatia) and OECD countries. As resources allocated to education and R\&D sector are significantly limited, a special emphasis should be given to their efficient use regarding the institutional and legal constraints. By applying non-parametric methodology, i.e. Data Envelopment Analysis (DEA), a relative efficiency is defined as the deviation from the efficiency frontier which represents the maximum output/outcome attainable from each input level. An analysis of (output-oriented) efficiency measures shows that among the new EU member states Hungary, Estonia and Slovenia seem to be good benchmark countries in the field of primary, secondary and tertiary education, respectively. On the other hand, Cyprus and again Hungary dominate in the field of R\&D sector, even if for different reasons. The empirical results also suggest that, in general, new EU member states show relatively high efficiency in tertiary education, while lag well behind in the R\&D efficiency measures.
\end{abstract}

Keywords: public spending, education, R\&D, technical efficiency, DEA analysis, new EU members, OECD.

Reference to this paper should be made as follows: Aristovnik, A. 2012. The relative efficiency of education and R\&D expenditures in the new EU member states, Journal of Business Economics and Management 13(5): 832-848.

JEL Classification: C14, H50, I21, O30.

\section{Introduction}

Each nation's future wealth and competitive position in the globalised world depends increasingly on its ability to create and absorb knowledge. An essential feature of knowledge is that it requires human capital (educated persons) for both its production and its application. Indeed, long-term economic growth of the economy rests with its capacity to increase productivity through rapid technological progress. Therefore, the national systems of education and research and development $(R \& D)$ are the quintessential tools for the creation and application of knowledge. However, as most of the countries are faced with increasing demands on their limited (public) resources, there is an increasing pressure to improve resource allocation and utilisation. Accordingly, policy makers 
in a number of countries became increasingly concerned with measuring efficiency. With education and R\&D expenditures comprising a relatively important amount of national income, the interest in examining whether such expenditures are cost-effective has increased, recently.

The paper joins the efforts of other scholars in investigating education and R\&D efficiency by applying a non-parametric methodology. Hence, the purpose of the paper is to review some previous researches on the efficiency measurement of public education and $\mathrm{R} \& \mathrm{D}$ sectors as well as some conceptual and methodological issues of non-parametric approach. Most importantly, Data Envelopment Analysis (DEA) technique is presented and then applied to the wide range of the EU and OECD countries, including new EU member states ${ }^{1}$, to evaluate technical efficiency within the both selected sectors. The importance of examining public sector expenditure efficiency is particularly pronounced for emerging market economies where public resources are normally insufficient. When services are publicly provided, performance measurement becomes an inevitable management tool because when inefficiency continues, the constituents of that inefficient unit suffer. The government needs benchmarking tools to provide incentives to good performing sectors and to induce inefficient sectors to perform better. However, the focus of the paper is not on how to cut (public) expenditures, but rather more on investigating potential reserves to increase the value for money of public spending, i.e. how to make the most of limited public (and private) resources ${ }^{2}$.

The paper is organized as follows. In the next section we present a brief literature review of measuring public education and R\&D expenditure efficiency. Section 3 shows a theoretical background of non-parametric methodologies with special focus on Data Envelopment Analysis (DEA) and the specifications of the models. Section 4 outlines the results of the non-parametric efficiency analysis of both, education and R\&D sector. The final section provides concluding remarks and some policy implications.

\section{A brief literature review}

Previous studies on the performance and efficiency of the public sector (at national level) that applied non-parametric methods find significant divergence of efficiency across countries. Studies include notably Fakin and Crombrugghe (1997) for the public sector, Gupta and Verhoeven (2001) for education and health in Africa, Clements (2002) for education in Europe, Aubyn (2003) for education spending in the OECD, Afonso et al. $(2005,2006)$ for public sector performance expenditure in the OECD and in emerging markets, Afonso and St. Aubyn (2005, 2006a, 2006b) for efficiency in providing health and education in OECD countries. De Borger and Kerstens (1996), and Afonso and Fer-

\footnotetext{
${ }^{1}$ In this paper, the group of new EU member states consists of Bulgaria, Cyprus, Czech R., Estonia, Hungary, Latvia, Lithuania, Poland, Romania, Slovakia and Slovenia.

${ }^{2}$ Note, however, that it is not only public expenditure but also tax regulatory policies that affect the efficiency of the public sector. While expenditure is a relatively good proxy of the tax burden, we ignore the composition of tax revenue and other characteristics of tax system.
} 
nandes (2006) find evidence of spending inefficiencies for the local government sector. Additionally, Afonso et al. (2008) assess the efficiency of public spending in redistributing income. Most studies apply the Data Envelopment Analysis (DEA) method while Afonso and Aubyn (2006a) undertook a two-step DEA/Tobit analysis, in the context of a cross-country analysis of secondary education efficiency.

Other authors (e.g. Mandl et al. 2008; Jafarov, Gunnarsson 2008) have tried to improve on the work by Afonso et al. (2005). The country-clusters resulted are very similar. Southern European countries present low general and educational performance, new EU member states show low general performance but high educational one, and the Northern European and Anglo-Saxon countries with high scores in both items (although the differences among countries in the educational performance are high; e.g. Luxembourg with a high macroeconomic score but fairly poor results for the effectiveness of its education system).

While there are a number of studies that examine technical efficiency in education (see also Castano, Cabanda 2007; Grosskopf, Mourtray 2001; Johnes 1996, 2006; Johnes, J., Johnes, G. 1995; Ng, Li 2000; Cherchye et al. 2010), very few recent studies examined the efficiency of countries in utilizing R\&D expenditure (Wang, Huang 2007; Sharma, Thomas 2008; Liu 2010; Zhong et al. 2011). Using data envelopment analysis (DEA) for education and R\&D, various groups of countries were benchmarked such as the OECD (Afonso, Aubyn 2005; Afonso et al. 2005; Jafarov, Gunnarsson 2008), African countries (Gupta, Verhoeven 2001), and developing countries (De Sijpe, Rayp 2004; Herrera, Pang 2005; Zhong et al. 2011). However, very insightful, cross-country analyses, particularly for both sectors, i.e. education and R\&D sector, are rarely used for policy analysis. This gap in the literature is addressed in the next sections of this paper where DEA approach is applied to several EU (plus Croatia) and OECD countries.

\section{Non-parametric methodology for assessing efficiency in public sector}

The measurement of efficiency generally requires: (a) an estimation of costs; (b) an estimation of output; and (c) the comparison between the two. Applying this concept to the spending activities of governments, we can say that public expenditure is efficient when, given the amount spent, it produces the largest possible benefit for the country's population ${ }^{3}$. Often efficiency is defined in a comparative sense: the relation between benefits and costs in country $\mathrm{X}$ is compared with that of other countries. This can be done for total government expenditure, or for expenditure related to specific functions such as health, education, poverty alleviation, building of infrastructures and so on. If in country $\mathrm{X}$ the benefits exceed the costs by a larger margin than in other countries, then public expenditure in country $\mathrm{X}$ is considered more efficient. However, the measurement of public efficiency is relatively complicated as comparison and measurement of both costs and benefits may be difficult. Deficient budgetary classifications, lack of reliable data, difficulties in allocating fixed costs to a specific function, and failure to

\footnotetext{
${ }^{3}$ The word benefit is used because economists often make a distinction between output and outcome.
} 
impute some value to the use of public assets used in the activity can also hamper the determination of real costs ${ }^{4}$.

Figure 1 illustrates the link between input, output and outcome, the main components of efficiency and effectiveness indicators. The monetary and non-monetary resources deployed (i.e. the input) produce an output. For example, education spending (input) affects number of students completing a grade (output). The input-output ratio is the most basic measure of efficiency ${ }^{5}$. However, compared to productivity measurement, the efficiency concept incorporates the idea of the production possibility frontier, which indicates feasible output levels given the scale of operations. The greater the output for a given input or the lower the input for a given output, the more efficient the activity is. Productivity, by comparison, is simply the ratio of outputs produced to input used.

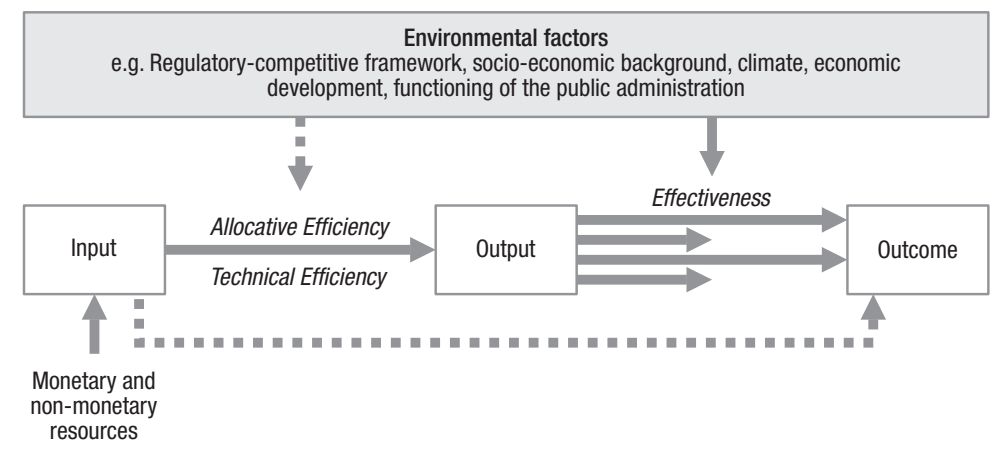

Fig. 1. Conceptual framework of efficiency and effectiveness Source: Mandl et al. (2008)

On the other hand effectiveness relates the input or the output to the final objectives to be achieved, i.e. the outcome. The outcome is often linked to welfare or growth objectives and therefore may be influenced by multiple factors (including outputs but also exogenous 'environment' factors). The effectiveness is more difficult to assess than efficiency, since the outcome is influenced by political choice. The distinction between output and outcome is often blurred and output and outcome are used in an interchangeable manner, even if the importance of the distinction between both concepts is recognized. For example, the outputs of a health system are often measured in terms of the number of operations performed or days spent in a hospital. The final outcome, however, could be how many patients got well enough to return to an active life. Thus, the effectiveness shows the success of the resources used in achieving the objectives set.

A common approach to measure efficiency is based on the concept of efficiency frontier (productivity possibility frontier). There are multiple techniques to calculate or

\footnotetext{
${ }^{4}$ More about measuring costs and efficiency of public spending see Afonso et al. (2006).

${ }^{5}$ When measuring efficiency, a distinction can be made between technical and allocative efficiency. Technical efficiency measures the pure relation between inputs and outputs taking the production possibility frontier into account. On the other hand, allocative inefficiency occurs if the distribution of particular public sector outputs is not in accordance with personal preferences (Bailey 2002: 119).
} 
estimate the shape of the efficiency frontier. Most investigations aimed at measuring efficiency are based either on parametric or non-parametric methods. The main difference between the parametric and the non-parametric approach is that parametric frontier functions require the ex-ante definition of the functional form of the efficiency frontier. While a parametric approach assumes a specific functional form for the relationship between input and output, a non-parametric approach constructs an efficiency frontier using input/output data for the whole sample following a mathematical programming method $^{6}$. A calculated frontier provides a benchmark by which the efficiency performance can be judged. This technique is therefore primary data-driven. Among the different non-parametric methods the Free Disposal Hull (FDH) technique imposes the fewest restrictions ${ }^{7}$. It follows a stepwise approach to construct the efficiency frontier. Along this production possibility frontier one can observe the highest possible level of output/outcome for a given level of input. Conversely, it is possible to determine the lowest level of input necessary to attain a given level of output/outcome. This allows identifying inefficient producers both in terms of input efficiency and in terms of output/ outcome efficiency (Afonso et al. 2005).

An alternative non-parametric technique that has recently started to be commonly applied to (public) expenditure analysis is Data Envelopment Analysis (DEA) ${ }^{8}$. DEA is a non-parametric frontier estimation methodology originally introduced by Charnes, Cooper, and Rhodes in 1978 that compares functionally similar entities described by a common set of multiple numerical attributes. DEA classifies the entities into "efficient" or "performers" versus "inefficient" or "non-performers". According to DEA framework, the inefficiencies are the degrees of deviance from the frontier. Input inefficiencies show the degree to which inputs must be reduced for the inefficient country to lie on the efficient practice frontier. Output inefficiencies are the needed increase in outputs for the country to become efficient. If a particular country either reduces its inputs by the inefficiency values or increases its outputs by the amount of inefficiency, it could become efficient; that is, it could obtain an efficiency score of one. The criterion for classification is determined by the location of the entities' data point with respect to the efficient frontier of the production possibility set. The classification of any particular entity can be achieved by solving a linear program (LP).

Various types of DEA models can be used, depending upon the problem at hand. The DEA model we use can be distinguished by the scale and orientation of the model. If one cannot assume that economies of scale do not change, then a variable returns- toscale (VRS) type of DEA model, the one selected here, is an appropriate choice (as opposed to a constant-returns-to-scale, (CRS) model). Furthermore, if in order to achieve better efficiency, governments' priorities are to adjust their outputs (before inputs), then an output-oriented DEA model rather than an input-oriented model is appropriate. The

\footnotetext{
${ }^{6}$ For an overview of non-parametric techniques see Simar and Wilson (2003).

${ }^{7}$ FDH analysis was first proposed by Deprins et al. (1984).

${ }^{8}$ DEA analysis, originating from Farrell's (1957) seminal work was originally developed and applied to firms that convert inputs into outputs (see Coelli et al. (2002) for a number of applications).
} 
way in which the DEA program computes efficiency scores can be explained briefly using mathematical notation (adapted from Ozcan 2007). The VRS envelopment formulation is expressed as follows:

$$
\begin{aligned}
& \operatorname{VRS}_{\mathrm{p}}\left(\mathrm{Y}_{1}, \mathrm{X}_{1}, \mathbf{u}^{1}, \mathbf{v}^{1}\right): \min -\left(\mathbf{u}^{1} \mathrm{~s}+\mathbf{v}^{1} \mathrm{e}\right) \\
& \mathbf{Y} \lambda-\mathrm{s}=\mathrm{Y}_{1} \\
& -\mathbf{X} \lambda-\mathrm{e}=-\mathrm{X}_{1} ; \\
& \mathbf{1} \lambda=1 \\
& \lambda \geq 0, \mathrm{e} \geq 0, \mathrm{~s} \geq 0
\end{aligned}
$$

For decision making unit $1, \mathrm{x}_{\mathrm{i} 1} \geq 0$ denotes the $\mathrm{i}^{\text {th }}$ input value, and $\mathrm{y}_{\mathrm{i} 1} \geq 0$ denotes the $\mathrm{r}^{\text {th }}$ output value. $\mathrm{X}_{1}$ and $\mathrm{Y}_{1}$ denote, respectively, the vectors of input and output values. Units that lie on (determine) the surface are deemed efficient in DEA terminology. Units that do not lie on the surface are termed inefficient. Optimal values of variables for decision making unit 1 are denoted by the s-vector $\mathrm{s}^{1}$, the $\mathrm{m}$-vector $\mathrm{e}^{1}$, and the $\mathrm{n}$-vector $\lambda^{1}$.

Although DEA is a powerful optimization technique that can assess the performance of each country, it has certain limitations. When one has to deal with large numbers of inputs and outputs, and a small number of countries are under evaluation, the discriminatory power of the DEA is limited. However, analysts can overcome this limitation by including only those factors (input and output) that provide the essential components of "production", thus avoiding distortion of the DEA results. This is usually done by eliminating one of a pair of factors that are strongly positively correlated with each other.

In the majority of studies using DEA, the data are analyzed cross-sectionally, with each decision making unit (DMU) - in this case the country - being observed only once. Nevertheless, data on DMUs are often available over multiple time periods. In such cases, it is possible to perform DEA over time, where each DMU in each time period is treated as if it were a distinct DMU. However, in our case the data set for all the tests in the study includes an average data for the 1999-2007 period (including PISA 2006 average scores) in order to evaluate long-term efficiency measures as education and R\&D processes are characterized by time lags in up to $37 \mathrm{EU}$ (plus Croatia) and OECD countries. The program used for calculating the technical efficiencies is the DEAFrontier software. The data are provided by Eurostat, OECD, UNESCO and the World Bank's World Development Indicators database.

The specification of the outputs and inputs is a crucial first step in DEA, since the larger the number of outputs and inputs included in any DEA, the higher will be the expected proportion of efficient DMUs, and the greater will be the expected overall average efficiency (Chalos 1997). Common measures of teaching output in education used in previous studies are based on graduation and/or completion rates (see Johnes 1996; Jafarov, Gunnarsson 2008), PISA scores (see Afonso, Aubyn 2005; Jafarov, Gunnarsson 2008) pupil-teacher ratio and enrolment rate (see Jafarov, Gunnarsson 2008). On the other hand, the outputs of the R\&D process are usually patents and publications (see Wang, Huang 2007; Sharma, Thomas 2008). Moreover, the literature shows that the specifica- 
tion of the inputs is generally in the form of domestic (public or total) expenditure (in $\%$ of GDP) (for education or R\&D) or the number of teachers (or researchers) per million inhabitants. Nevertheless, these studies also demonstrate that DEA is an effective research tool for evaluating the efficiency of education and R\&D sectors, given varying input mixes and types and numbers of outputs.

Hence, similar to the former empirical literature, in this analysis the data set to evaluate education sector efficency (at different levels) includes input data, i.e. (public) expenditure per student, tertiary ( $\%$ of GDP per capita) or total expenditure on education (in $\%$ of GDP) and output/outcome data, i.e. school enrolment, tertiary (\% gross), teacher/pupil ratio, primary completion rate, total ( $\%$ of relevant age group), unemployment with tertiary education ( $\%$ of total unemployment), labor force with tertiary education $(\%$ of total) and PISA 2006 average score. There are up to thirty-seven countries included in the analysis (selected EU (plus Croatia) and OECD countries). Different inputs and outputs/outcomes have been tested in four models (see Table 1).

Table 1. Input and output/outcome set for the DEA - Education Sector (at different levels)

\begin{tabular}{|c|c|c|}
\hline Model & Inputs & Outputs/Outcomes \\
\hline $\begin{array}{c}1 \\
\text { (Primary) }\end{array}$ & $\begin{array}{l}\text { Expenditure per student, primary } \\
(\% \text { of GDP per capita })^{2}\end{array}$ & $\begin{array}{l}\text { - School enrolment, primary (\% gross) } \\
\text { - Pupil-teacher ratio in primary education }{ }^{2} \\
\text { - Primary completion rate, total (\% of } \\
\text { relevant age group) })^{2}\end{array}$ \\
\hline $\begin{array}{c}2 \\
\text { (Secondary) }\end{array}$ & $\begin{array}{l}\text { Public expenditure per pupil as } \\
\text { a } \% \text { of GDP per capita. Secondary } 1\end{array}$ & $\begin{array}{l}\text { - PISA } 2006 \text { Average }^{3} \\
\text { - School enrolment, secondary (\% gross) }{ }^{2} \\
\text { - Pupil-teacher ratio. Secondary }{ }^{1}\end{array}$ \\
\hline $\begin{array}{c}3 \\
\text { (Tertiary) }\end{array}$ & $\begin{array}{l}\text { Expenditure per student, tertiary } \\
(\% \text { of GDP per capita })^{2}\end{array}$ & $\begin{array}{l}\text { - Unemployment with tertiary education } \\
(\% \text { of total unemployment })^{2} \\
\text { - Labor force with tertiary education } \\
(\% \text { of total })^{2} \\
\text { - School enrolment, tertiary }(\% \text { gross })^{2}\end{array}$ \\
\hline $\begin{array}{c}4 \\
(\text { Total })\end{array}$ & $\begin{array}{l}\text { Total expenditure on education, } \\
(\text { in } \% \text { of GDP })^{2}\end{array}$ & - PISA 2006 Average \\
\hline
\end{tabular}

Sources: ${ }^{1} \mathrm{UNESCO} ;{ }^{2}$ World Bank; ${ }^{3} \mathrm{OECD}$

Moreover, to test a relative efficiency of $R \& D$ sector, additional quantative input and output data is collected and processed. The inputs of the R\&D process are total expenditure on $\mathrm{R} \& \mathrm{D}$ (as a \% of GDP) and researchers in R\&D (per million people). The output can be in the form of publications or patents (see Sharma, Thomas 2008), therefore the raw data for output employed in this study comprises total European patent applications (per million people), scientific and technical journal articles (per million people), and high-technology exports (\% of manufactured exports). Table 2 shows the input and output/outcome data used in four different models. 
Table 2. Input and output/outcome set for the DEA - R\&D Sector

\begin{tabular}{|c|c|c|}
\hline Model & Inputs & Outputs/Outcomes \\
\hline I & $\begin{array}{l}\text { Total expenditure } \\
\text { on R\&D } \\
\text { (as a } \% \text { of GDP) }\end{array}$ & $\begin{array}{l}\text { - Total European patent applications } \\
(\text { per million people })^{3}\end{array}$ \\
\hline II & $\begin{array}{l}\text { Total expenditure } \\
\text { on } \mathrm{R} \& \mathrm{D} \\
\text { (as a } \% \text { of GDP) }\end{array}$ & $\begin{array}{l}\text { - Total European patent applications (per million people) } \\
\text { - Scientific and technical journal articles (per million people) }\end{array}$ \\
\hline III & $\begin{array}{l}\text { Total expenditure } \\
\text { on } \mathrm{R} \& \mathrm{D} \\
\text { (as a } \% \text { of GDP) }\end{array}$ & $\begin{array}{l}\text { - Total European patent applications (per million people) } \\
\text { - Scientific and technical journal articles (per million people) } \\
\text { - High-technology exports ( } \% \text { of manufactured exports })^{2}\end{array}$ \\
\hline IV & $\begin{array}{l}\text { Total expenditure } \\
\text { on R\&D } \\
\text { (as a \% of GDP) } \\
\text { Researchers in R\&D } \\
\text { (per million people) }\end{array}$ & $\begin{array}{l}\text { - Total European patent applications (per million people) } \\
\text { - Scientific and technical journal articles (per million people) } \\
\text { - High-technology exports (\% of manufactured exports) }\end{array}$ \\
\hline
\end{tabular}

Sources: ${ }^{1}$ UNESCO; ${ }^{2}$ World Bank; ${ }^{3}$ Eurostat

\section{Empirical results}

\subsection{Education efficiency results}

This subsection shows the empirical application of the Data Envelopment Analysis (DEA) ${ }^{9}$. When looking at the education results ${ }^{10}$, by using model 1 (see Table 1) and applying the DEA efficiency frontier technique within a selected group of EU/OECD countries and Croatia to measure efficiency of primary education, Denmark, Hungary and Portugal are seen as most efficient. The efficient countries are also Greece, Iceland and Romania, however, their primary expenditures per student (in \% of GDP) is very low and have averaged less than $12 \%$ (the EU/OECD average is $18.7 \%$ in the considered period). One can also see that some countries come very close to the frontier (e.g. Czech R. and Italy), while the other countries are further away and therefore less efficient (e.g. Turkey and Croatia) (see Table 3). Some less efficient countries should significantly decrease their input (primary expenditure per student) (e.g. Slovenia from $27.0 \%$ to $22.0 \%$ ) and/or increase their outputs, i.e. school enrolment (e.g. Ireland and Poland), primary completion rate (Belgium) and teacher-pupil ratio (Turkey and Ireland) in order to become efficient ${ }^{11}$. Interestingly, the new EU member states are, in general,

\footnotetext{
${ }^{9}$ All the calculated results are available from the author on request.

${ }^{10} \mathrm{All}$ of the results relate to DEA with an output orientation, allowing for variable returns to scale (VRS). An output orientation focuses on the amount by which output quantities can be proportionally increased without changing the input quantities used. Using an input orientation approach leads to similar efficiency results as those presented in the text.

${ }^{11}$ The average output efficiency score for primary education is 1.050 , which means that the average country could increase the outputs/outcomes for about $5.0 \%$ if it were efficient. The results also confirm our expectations, that larger public sector increases the inefficiency in a primary education.
} 
relatively more efficient than non-EU countries in the sample, however, they show relatively low efficiency against the old EU-member states.

In terms of the efficiency scores of secondary education, even ten analyzed countries are labeled as efficient (see Table 3), however, only Romania and Slovakia represents new EU member states in this group of efficient countries. The average output efficiency score is 1.06715 , which means that the average country could increase the outputs/ outcomes for almost $7.0 \%$ if it were efficient. The worse performers are Mexico and Bulgaria with a well below average PISA scores (considerably less than 490), school enrolment (significantly less than $103.6 \%$ ) and teacher-pupil ratio (less than 0.086 ). Indeed, both countries should increase their outputs by more than $10 \%$ in order to become an efficient (similar to the new EU member states average efficiency, which is the least efficient sub-group in the analysis).

When testing tertiary education efficiency, eleven among the 37 countries analyzed within the formulation for tertiary education presented in Table 1 were estimated as efficient. These countries are Canada, Czech R., Finland, Korea, Latvia, Lithuania, Poland, Russia, Slovakia, Slovenia and the United States. The results of the DEA analysis (Model 3) also suggest a relatively high level of inefficiency in tertiary education in a wide range of countries and, correspondingly, significant room to rationalize public spending without sacrificing, while also potentially improving tertiary outputs and outcomes. Indeed, the countries under consideration could improve their efficiency scores by decreasing their input (expenditure per student (in \% of BDP)), in particular in Denmark and Switzerland. However, even more importantly, a significant increase of outputs/outcomes is need in the form of school enrolment (in particular in Cyprus and Mexico), and in the form of labour force with tertiary education (in Portugal, Turkey and Romania). In general, output/outcome scores could be higher for about $6 \%$ on average. Interestingly, non-EU member states show significantly worse DEA scores as they should increase their tertiary outputs/outcomes by more than $13 \%$ (in comparison to the old EU member states for about $7 \%$ and the new EU member states only for 1.4\%).

Further empirical analysis, testing the efficiency of the total expenditure on education (Model 4), shows that the worse efficiency performers are Bulgaria, Romania and Portugal (see Table 4). Indeed, if these countries employed the resources in efficient manner, they could increase their PISA scores by $19.5 \%, 15.6 \%$ and $13.6 \%$, respectively. The main reason for the education inefficiency in these countries lies in transforming intermediate education outputs into real outcomes (see IMF 2008) (same problems have some other new EU member states, particularly Latvia, Lithuania and Hungary). The results also show that the best performers (in terms of efficiency) seem to be Finland and Japan, while Greece presents a good efficiency result due the lowest education spending (averaged only 3.6\% of GDP in 1999-2007). Interestingly, output-oriented DEA results confirm that Scandinavian countries could attain the same result with lowering their education expenditure by up to 2.3 percentage points (in Denmark). However, the new EU member states, in general, show the same efficiency as the old EU member states (both groups could increase their PISA scores by around $10 \%$ on average). 
Table 3. The relative efficiency of the EU member states (plus Croatia) and OECD countries in education

(Distribution by quartiles of the ranking of efficiency scores)

\begin{tabular}{|c|c|c|c|c|}
\hline Level & I. quartile & II. quartile & III. quartile & IV. quartile \\
\hline $\begin{array}{l}\text { Primary } \\
\text { education }\end{array}$ & $\begin{array}{l}\text { Denmark } \\
\text { Greece } \\
\text { Hungary } \\
\text { Iceland } \\
\text { Portugal } \\
\text { Romania } \\
\text { Czech Republic } \\
\text { Italy }\end{array}$ & $\begin{array}{l}\text { Spain } \\
\text { Slovakia } \\
\text { Germany } \\
\text { Norway } \\
\text { Austria } \\
\text { Finland }\end{array}$ & $\begin{array}{l}\text { Lithuania } \\
\text { Netherlands } \\
\text { Ireland } \\
\text { France } \\
\text { Bulgaria } \\
\text { Cyprus } \\
\text { Estonia } \\
\text { United States }\end{array}$ & $\begin{array}{l}\text { Slovenia } \\
\text { Poland } \\
\text { Latvia } \\
\text { Turkey } \\
\text { Croatia } \\
\text { Sweden } \\
\text { Belgium }\end{array}$ \\
\hline $\begin{array}{l}\text { Secondary } \\
\text { education }\end{array}$ & $\begin{array}{l}\text { Belgium } \\
\text { Finland } \\
\text { Greece } \\
\text { Ireland } \\
\text { Korea } \\
\text { Netherlands } \\
\text { Norway } \\
\text { Portugal } \\
\text { Romania } \\
\text { Slovakia }\end{array}$ & $\begin{array}{l}\text { New Zealand } \\
\text { Denmark } \\
\text { Estonia } \\
\text { Czech Republic } \\
\text { Japan } \\
\text { Sweden }\end{array}$ & $\begin{array}{l}\text { Hungary } \\
\text { Austria } \\
\text { Lithuania } \\
\text { Poland } \\
\text { Germany } \\
\text { Iceland } \\
\text { Latvia } \\
\text { Slovenia } \\
\text { Croatia }\end{array}$ & $\begin{array}{l}\text { Spain } \\
\text { France } \\
\text { Italy } \\
\text { United Kingdom } \\
\text { Bulgaria } \\
\text { Mexico } \\
\text { United States }\end{array}$ \\
\hline $\begin{array}{l}\text { Tertiary } \\
\text { education }\end{array}$ & $\begin{array}{l}\text { Canada } \\
\text { Czech Republic } \\
\text { Finland } \\
\text { Korea } \\
\text { Latvia } \\
\text { Lithuania } \\
\text { Poland } \\
\text { Russia } \\
\text { Slovakia } \\
\text { Slovenia } \\
\text { United States }\end{array}$ & $\begin{array}{l}\text { Hungary } \\
\text { Romania } \\
\text { Bulgaria } \\
\text { Australia } \\
\text { Austria } \\
\text { Ireland } \\
\text { Italy } \\
\text { Greece }\end{array}$ & $\begin{array}{l}\text { Portugal } \\
\text { Estonia } \\
\text { United Kingdom } \\
\text { Sweden } \\
\text { Japan } \\
\text { New Zealand } \\
\text { Croatia } \\
\text { Norway } \\
\text { Belgium }\end{array}$ & $\begin{array}{l}\text { Turkey } \\
\text { Iceland } \\
\text { Switzerland } \\
\text { Spain } \\
\text { Netherlands } \\
\text { France } \\
\text { Denmark } \\
\text { Mexico } \\
\text { Cyprus }\end{array}$ \\
\hline
\end{tabular}

Notes: Relative efficiency scores are based on models presented in Table 1. The countries are ranked from the most efficient (e.g. Denmark ranks 1st for primary education) to the least efficient (Belgium ranks 29th). Thirty-seven (or less) countries are included in the analysis (EU-27, OECD and Croatia). The new EU member states are presented in italic.

Sources: World Bank (2010); UNESCO (2010); OECD (2010); own calculations

\section{2. $R \& D$ efficiency results}

The results of the output-oriented VRS formulation of DEA analysis (based on Models I-IV in Table 2) suggest a relatively high level of inefficiency in R\&D sector in selected EU and OECD countries and, correspondingly, significant room to rationalize this spending without sacrificing, while also potentially improving, R\&D outputs and outcomes (see Table 5). Indeed, from the empirical results it may be seen that the total number of efficient countries varies significantly from one model to the other. There are only two technically efficient countries in Model I, i.e. Cyprus and Switzerland. 
Table 4. The relative efficiency of the selected EU member states (plus Croatia) and OECD countries in education

(Distribution by quartiles of the ranking of efficiency scores) (Model 4)

\begin{tabular}{|c|c|c|c|}
\hline Country & Output-Oriented VRS Efficiency & Rank & Benchmarks \\
\hline Finland & 1.00000 & 1 & \\
\hline Greece & 1.00000 & 1 & \\
\hline Japan & 1.00000 & 1 & \\
\hline Czech R. & 1.01370 & 4 & Greece, Japan \\
\hline Netherlands & 1.01971 & 5 & Finland, Japan \\
\hline Slovakia & 1.04248 & 6 & Greece, Japan \\
\hline Estonia & 1.04817 & 7 & Finland, Japan \\
\hline Germany & 1.05221 & 8 & Finland, Japan \\
\hline Iceland & 1.05541 & 9 & Finland, Japan \\
\hline Switzerland & 1.07374 & 10 & Finland, Japan \\
\hline Croatia & 1.07427 & 11 & Greece, Japan \\
\hline Poland & 1.07577 & 12 & Finland, Japan \\
\hline Spain & 1.07915 & 13 & Greece, Japan \\
\hline Belgium & 1.08288 & 14 & Finland \\
\hline Ireland & 1.08607 & 15 & Finland \\
\hline Austria & 1.08700 & 16 & Finland, Japan \\
\hline United Kingdom & 1.08986 & 17 & Finland, Japan \\
\hline Slovenia & 1.09281 & 18 & Finland \\
\hline Hungary & 1.09307 & 19 & Finland, Japan \\
\hline Sweden & 1.09620 & 20 & Finland \\
\hline Denmark & 1.10320 & 21 & Finland \\
\hline Italy & 1.10961 & 22 & Finland, Japan \\
\hline Turkey & 1.11606 & 23 & Greece, Japan \\
\hline France & 1.11721 & 24 & Finland, Japan \\
\hline Lithuania & 1.12536 & 25 & Finland, Japan \\
\hline Latvia & 1.13250 & 26 & Finland, Japan \\
\hline Norway & 1.13547 & 27 & Finland \\
\hline Portugal & 1.13607 & 28 & Finland, Japan \\
\hline Romania & 1.15600 & 29 & Greece, Japan \\
\hline Bulgaria & 1.19523 & 30 & Greece, Japan \\
\hline Mean & 1.082974 & & \\
\hline Std. Dev. & 0.046890 & & \\
\hline
\end{tabular}

Notes: Relative efficiency scores are based on Model 4 presented in Table 1. Thirty-seven (or less) countries are included in the analysis (EU-27, OECD and Croatia). The new EU member states are presented in italic. Sources: World Bank (2010); UNESCO (2010); OECD (2010); own calculations 
Table 5. DEA results for R\&D efficiency in selected OECD and EU (plus Croatia) countries

\begin{tabular}{|c|c|c|c|c|c|c|c|c|c|}
\hline \multirow[t]{2}{*}{ No. } & \multirow[t]{2}{*}{ Country } & \multicolumn{2}{|c|}{ Model 1} & \multicolumn{2}{|c|}{ Model 2} & \multicolumn{2}{|c|}{ Model 3} & \multicolumn{2}{|c|}{ Model 4} \\
\hline & & VRSTE & Rank & VRSTE & Rank & VRSTE & Rank & VRSTE & Rank \\
\hline 1 & Austria & 1.813141 & 9 & 1.772511 & 11 & 1.74299 & 19 & 1.74299 & 20 \\
\hline 2 & Belgium & 1.946127 & 10 & 1.798519 & 12 & 1.798519 & 20 & 1.798519 & 21 \\
\hline 3 & Bulgaria & 16.97258 & 26 & 4.126472 & 23 & 3.257727 & 29 & 3.257727 & 30 \\
\hline 4 & Croatia & 18.50990 & 28 & 8.197272 & 30 & 2.505924 & 22 & 2.263016 & 22 \\
\hline 5 & Cyprus & 1.00000 & 1 & 1.00000 & 1 & 1.00000 & 1 & 1.00000 & 1 \\
\hline 6 & Czech R. & 18.04899 & 27 & 7.376771 & 29 & 2.389574 & 21 & 2.389574 & 23 \\
\hline 7 & Denmark & 1.804187 & 8 & 1.624639 & 10 & 1.413926 & 14 & 1.413926 & 16 \\
\hline 8 & Estonia & 14.66091 & 25 & 4.350404 & 25 & 1.028351 & 6 & 1.028351 & 7 \\
\hline 9 & Finland & 1.470816 & 5 & 1.416727 & 6 & 1.121134 & 8 & 1.121134 & 9 \\
\hline 10 & France & 2.353204 & 12 & 2.23791 & 16 & 1.532798 & 17 & 1.532798 & 18 \\
\hline 11 & Germany & 1.185866 & 4 & 1.185866 & 5 & 1.185866 & 10 & 1.185866 & 12 \\
\hline 12 & Greece & 5.166897 & 19 & 1.485402 & 8 & 1.23332 & 11 & 1.23332 & 13 \\
\hline 13 & Hungary & 7.921077 & 22 & 4.251266 & 24 & 1.00000 & 1 & 1.00000 & 1 \\
\hline 14 & Iceland & 3.833561 & 17 & 1.00000 & 1 & 1.00000 & 1 & 1.00000 & 1 \\
\hline 15 & Ireland & 2.615933 & 15 & 2.615933 & 17 & 1.416829 & 15 & 1.416829 & 17 \\
\hline 16 & Italy & 1.689301 & 7 & 1.529446 & 9 & 1.529446 & 16 & 1.185155 & 10 \\
\hline 17 & Japan & 2.236736 & 11 & 2.236736 & 15 & 1.297022 & 12 & 1.297022 & 14 \\
\hline 18 & Latvia & 7.246675 & 21 & 4.707793 & 26 & 2.818828 & 24 & 2.818828 & 25 \\
\hline 19 & Lithuania & 26.77351 & 30 & 8.615385 & 31 & 3.375551 & 30 & 3.375551 & 31 \\
\hline 20 & Netherlands & 1.095888 & 3 & 1.056028 & 4 & 1.00000 & 1 & 1.00000 & 1 \\
\hline 21 & Norway & 2.441297 & 13 & 1.926045 & 13 & 1.638207 & 18 & 1.638207 & 19 \\
\hline 22 & Poland & 21.70377 & 29 & 4.077039 & 22 & 4.077039 & 31 & 4.077039 & 32 \\
\hline 23 & Portugal & 13.41302 & 24 & 5.074669 & 27 & 2.627625 & 23 & 2.627625 & 24 \\
\hline 24 & Romania & 31.41902 & 31 & 6.039968 & 28 & 3.137808 & 27 & 3.137808 & 28 \\
\hline 25 & Slovakia & 11.18578 & 23 & 3.28307 & 21 & 2.908411 & 25 & 2.908411 & 26 \\
\hline 26 & Slovenia & 4.71298 & 18 & 3.236996 & 20 & 3.236996 & 28 & 3.236996 & 29 \\
\hline 27 & Spain & 5.212312 & 20 & 3.169643 & 19 & 2.93125 & 26 & 2.93125 & 27 \\
\hline 28 & Sweden & 1.570315 & 6 & 1.447259 & 7 & 1.350931 & 13 & 1.350931 & 15 \\
\hline 29 & Switzerland & 1.00000 & 1 & 1.00000 & 1 & 1.00000 & 1 & 1.00000 & 1 \\
\hline & Turkey & 55.19272 & 32 & 11.91257 & 32 & 7.363445 & 32 & 1.00000 & 1 \\
\hline & United King. & 2.548216 & 14 & 1.994522 & 14 & 1.100405 & 7 & 1.100405 & 8 \\
\hline & United States & 3.434942 & 16 & 2.936987 & 18 & 1.185618 & 9 & 1.185618 & 11 \\
\hline $\begin{array}{l}\text { Num } \\
\text { effic }\end{array}$ & $\begin{array}{l}\text { nber of } \\
\text { cient countries }\end{array}$ & 2 & & 3 & & 5 & & 6 & \\
\hline Mea & & 9.130615 & & 3.39637 & & 2.068923 & & 1.851716 & \\
\hline Std. & dev. & 11.7775 & & 2.610881 & & 1.321141 & & 0.916611 & \\
\hline
\end{tabular}

Note: Relative efficiency scores (Models I-IV; see Table 2). Thirty-two countries are included in the analysis (EU-27, OECD and Croatia). The new EU member states are presented in italic. VRSTE - Technical efficiency from variable return to scale DEA.

Sources: World Bank (2010); UNESCO (2010); Eurostat (2010); own calculations 
However, with around $0.33 \%$ of GDP Cyprus demonstrates the lowest level of the expenditure on R\&D among all the countries in the sample. The least efficient nations are Turkey, Romania, Lithuania and Poland as a results of an extremely low number of Total European patent applications (per million people), ranging from 0.74 (Romania) to 2.36 (Lithuania) (for instance, the EU/OECD group average is 82.2). In order to enhance the reliability of the findings, additional inputs and outputs/outcomes has been introduced, resulting in model II, III and IV (for details see also Table 2).

Adding another output in the form (Model II) of total number of scientific and technical journal articles (per million people), the results show Cyprus, Iceland and Switzerland to be technically most efficient countries. Not surprisingly, the increasing number of the outputs in a relatively small sample leads to a higher number of efficient countries. In general, the rankings remain relatively stable in comparison to the Model I (with Iceland $^{12}$ as only significant exception).

Table 6. The relative efficiency of R\&D sector in selected OECD and EU (plus Croatia) countries

(Distribution by quartiles of the ranking of efficiency scores in all four models)

\begin{tabular}{llll}
\hline \multicolumn{1}{c}{ I. quartile } & \multicolumn{1}{c}{ II. quartile } & \multicolumn{1}{c}{ III. quartile } & \multicolumn{1}{c}{ IV. quartile } \\
\hline Cyprus & United Kingdom & Belgium & Turkey \\
Switzerland & Denmark & Estonia & Portugal \\
Netherlands & Hungary & France & Czech Republic \\
Iceland & Greece & Norway & Croatia \\
Finland & Japan & Ireland & Bulgaria \\
Germany & United States & Spain & Poland \\
Sweden & Austria & Slovakia & Romania \\
Italy & & Slovenia & Lithuania \\
& & Latvia & \\
\hline
\end{tabular}

Note: Relative efficiency scores (Models I-IV; see Table 2) - the countries are ranked from the most efficient (e.g. Cyprus ranks 1st, Switzerland ranks 2nd, etc.) to the least efficient (e.g. Lithuania ranks 32nd). Thirty-two countries are included in the analysis (EU-27, OECD and Croatia). The new EU member states are presented in italic.

Sources: World Bank (2010); UNESCO (2010); Eurostat (2010); own calculations

Model III includes another outcome variable, i.e. high-technology exports (\% of manufactured exports), which represents the transfer of new knowledge and technology into export sector. Under this model there are two additional efficient nations, i.e. Hungary and Netherlands. Interestingly, the biggest ranking improvements are shown by Estonia and Hungary, with high-technology exports averages accounted for $22.8 \%$ and $25.3 \%$ in 1999-2007 period, respectively (the EU/OECD average is 15.1\%). In order to become an efficient nation, selected countries should significantly increase the number of Total

\footnotetext{
${ }^{12}$ In fact, Iceland seems to be an outlier, as it has an extremely high number of scientific and technical journal articles (on average 5.400 per million inhabitants in 1999-2007), which is around ten times higher in comparison to the group average. Nevertheless, by dropping Iceland from the sample, the results do not change considerably.
} 
European patent applications (per million people) (particularly in Poland, Romania, Turkey, Czech R. and Bulgaria), the number of scientific and technical journal articles (per million people) (particularly in highly populated countries, such as Japan and Germany), and the share of high-technology exports (in Belgium, Italy and Slovenia).

According to the presented empirical analysis, it is obvious that the R\&D sector in many considered countries suffers from relatively low technical efficiency. The inefficiency is particularly highlighted in the new EU member states (plus Croatia) and some less developed OECD members, i.e. emerging market economies (see Table 5). As most of these countries significantly lag behind as far as total expenditure on R\&D (in \% of GDP), it will be crucial for them to increase these resources in an efficient manner. Hence, the improvement of the sector's efficiency, which can significantly contribute to the development and the growth of the country, should therefore be a top priority practically for all countries in the near future.

\section{Conclusion}

In recent years, the debate of the role of the public sector has shifted significantly towards empirical assessments of the efficiency and usefulness of its activities. Indeed, tight budgets and demanding citizens put governments under increasing pressure to show that they are providing good value for money. Providing information about public sector performance can satisfy the public's need to know, and could also be a useful tool for governments to evaluate their performance. In this respect, the aim of the paper was to apply a common non-parametric method (Data Envelopment Analysis-DEA) to measure technical efficiency in two extremely important sectors that significantly determine long-run economic growth of the national economy, i.e. education and R\&D. Moreover, in the paper the analysis also shows how DEA can be used for classifications and rankings of the countries in two highly important sectors for national economy.

The empirical results show that technical efficiency in education and R\&D sectors differs significantly across the great majority of the EU (including new EU member states) and OECD countries. The analysis of different (output-oriented) efficiency (under VRS framework) shows that Japan, Korea and Finland seem to be the most efficient countries in the field of education sector, while Switzerland and Netherlands dominate in the field of R\&D sector. When focusing only on the new EU member states, Hungary, Estonia and Slovenia seem to be good efficiency performers in the field of primary, secondary and tertiary education, respectively. On the other hand, Cyprus and Hungary dominate in the field of R\&D sector, even if for different reasons. The empirical results also suggest that, in general, new EU member states show relatively high efficiency in tertiary education, while lag well behind in the R\&D efficiency measures. All in all, the analysis finds evidence that most of the new EU member states have a great potential for increased efficiency in (public) spending of limited education and R\&D resources.

However, a few limitations of the presented empirical study should be pointed out. Firstly, the applications of presented techniques are hampered by lack of suitable data to apply those techniques. Quality data are needed because the techniques available 
to measure efficiency are sensitive to outliers and may be influenced by exogenous factors. Indeed, substantial inefficiency may be simply a reflection of environmental factors (such as climate, socio-economic background, etc.). This also suggests applying a combination of techniques to measure efficiency. Secondly, the precise definition of inputs, outputs and outcomes may significantly influence the results. Finally, it seems important to bear in mind that by using a non-parametric approach, and in spite of DEA being an established and valid methodology, differences across countries are not statistically assessed, which can be considered as a limitation of such methodology. Hence, further research is clearly needed to eliminate the above deficiencies, in particular to test the influence of the environmental factors on education and R\&D sector efficiency.

\section{References}

Afonso, A.; Schuknecht, L.; Tanzi, V. 2005. Public sector efficiency: an international comparison, Public Choice 123(3-4): 321-347. http://dx.doi.org/10.1007/s11127-005-7165-2

Afonso, A.; Aubyn, St. 2005. Non-parametric approaches to education and health efficiency in OECD countries, Journal of Applied Economics 8(2): 227-246.

Afonso, A.; Aubyn, St. 2006a. Cross-country efficiency of secondary education provision: a semi-parametric analysis with non-discretionary inputs, Economic Modelling 23(3): 476-491. http://dx.doi.org/10.1016/j.econmod.2006.02.003

Afonso, A.; Aubyn, St. 2006b. Relative efficiency of health provision: a DEA approach with non-discretionary inputs. ISEG-UTL, Department of Economics Working Paper no 33/2006/DE/ UECE.

Afonso, A.; Schuknecht, L.; Tanzi, V. 2006. Public sector efficiency: evidence for new EU member states and emerging markets, Working Paper Series 581. European Central Bank: Frankfurt.

Afonso, A.; Fernandes, S. 2008. Assessing and explaining the relative efficiency of local government, Journal of Socio-Economics 37(5): 1946-1979.

http://dx.doi.org/10.1016/j.socec.2007.03.007

Afonso, A.; Schuknecht, L.; Tanzi, V. 2008. Income distribution determinants and public spending efficiency, Working Paper Series 861. European Central Bank: Frankfurt.

Aubyn, St. M. 2003. Evaluating efficiency in the Portuguese education sector, Economia 26: 25-51.

Castano, M. C.; Cabanda, E. 2007. Performance evaluation of the efficiency of Philippine Private Higher Educational Institutions: application of frontier approaches, Int. Trans. Oper. Res. 14: 431-444. http://dx.doi.org/10.1111/j.1475-3995.2007.00599.x

Chalos, P. 1997. An examination of budgetary inefficiency in education using data envelopment analysis, Financial Accountability \& Management 13(1): 55-69.

http://dx.doi.org/10.1111/1468-0408.00026

Cherchye, L.; De Witte, K.; Ooghe, E.; Nicaise, I. 2010. Efficiency and equity in private and public education: nonparametric comparison, European Journal of Operational Research 202(2): 563-573. http://dx.doi.org/10.1016/j.ejor.2009.06.015

Clements, B. 2002. How efficient is education spending in Europe?, European Review of Economics and Finance 1: 3-26.

Coelli, T.; Rao, D.; Battese, G. 2002. An Introduction to Efficiency and Productivity Analysis. 6th edition. Massachusetts, Kluwer Academic Publishers. 
Čadež, S.; Guilding, C. 2008. An exploratory investigation of an integrated contingency model of strategic management accounting, Account. Organ. Soc. 33(7/8): 836-863.

De Borger, B.; Kerstens, K. 1996. Cost efficiency of Belgian local governments: a comparative analysis of FDH, DEA, and econometric approaches, Regional Science and Urban Economics 26: 145-170. http://dx.doi.org/10.1016/0166-0462(95)02127-2

Deprins, D.; Simar, L.; Tulkens, H. 1984. Measuring labor-efficiency in post offices; in Marchand, M.; Pestieau, P.; Tulkens, H. (Eds.). The Performance of Public Enterprises: Concepts and Measurement. Amsterdam: North-Holland.

De Sijpe, N.; Rayp, G. 2004. Measuring and explaining government inefficiency in developing countries, Universitet Gent Working Paper 2004/266. Universitet Gent, Gent, 1-35.

Fakin, B.; de Crombrugghe, A. 1997. Fiscal adjustment in transition economies: social transfers and the efficiency of public spending: a comparison with OECD countries, Policy Research Working Paper 1803. Washington, DC: World Bank.

Farrell, M. 1957. The measurement of productive efficiency, Journal of the Royal Statistical Society Series A (General) 120(3): 253-281. http://dx.doi.org/10.2307/2343100

Grosskopf, S.; Mourtray, C. 2001. Evaluating performance in Chicago public high schools in the wake of decentralization, Econ. Educ. Rev. 20: 1-14.

http://dx.doi.org/10.1016/S0272-7757(99)00065-5

Gupta, S.; Verhoeven, M. 2001. The efficiency of government expenditure experiences from Africa, Journal of Policy Modelling 23: 433-467. http://dx.doi.org/10.1016/S0161-8938(00)00036-3

Herrera, S.; Pang, G. 2005. Efficiency of public spending in developing countries: an efficiency frontier approach, Policy Research Working Paper 3645. The World Bank, 1-67.

IMF. 2008. Republic of Croatia: selected issues, in IMF Publications. Washington.

Jafarov, E.; Gunnarsson, V. 2008. Government spending on health care and education in Croatia: efficiency and reform options, International Monetary Fund; IMF Working Paper WP/08/136.

Johnes, J. 1996. Performance assessment in higher education in Britain, Eur. J. Oper. Res. 89: $18-33$.

Johnes, J.; Johnes, G. 1995. Research funding and performance in U.K. university departments of economics: a frontier analysis, Econ. Educ. Rev. 14: 301-314.

http://dx.doi.org/10.1016/0272-7757(95)00008-8

Johnes, J. 2006. Data envelopment analysis and its application to the measurement of efficiency in higher education, Economics of Education Review 25(3): 273-288.

http://dx.doi.org/10.1016/j.econedurev.2005.02.005

Kaklauskas, A.; Zavadskas, E. K.; Budzeviciene, R. 2009. Web-based model of multiple criteria ethical decision-making for ethical behaviour of students, Journal of Business Economics and Management 10(1): 71-84. http://dx.doi.org/10.3846/1611-1699.2009.10.71-84

Klun, M. 2004. Performance measurement for tax administrations: the case of Slovenia, International Review of Administrative Sciences 70(3): 567-574.

http://dx.doi.org/10.1177/0020852304046210

Liu, J. S.; Lu, W. M. 2010. DEA and ranking with the network-based approach: a case of R\&D performance, Omega-International Journal of Management Science 38(6): 453-464.

http://dx.doi.org/10.1016/j.omega.2009.12.002

Mandl, U.; Dierx, A.; Ilzkovitz, F. 2008. The effectiveness and efficiency of public spending, Economic Papers 31, February. European Commission.

Markovic, M. R. 2009. Education through e-learning: case of Serbia, Journal of Business Economics and Management 10(4): 313-319. http://dx.doi.org/10.3846/1611-1699.2009.10.313-319 
Ng, Y. C.; Li, S. K. 2000. Measuring the research performance of Chinese higher education institutions: an application of data envelopment analysis, Educ. Econ. 8: 2-139.

Ozcan, Y. A. 2007. Health Care Benchmarking and Performance Evaluation: an Assessment using Data Envelopment Analysis (DEA). New York: Springer.

Sharma, S.; Thomas, V. J. 2008. Inter-country R\&D efficiency analysis: an application of data envelopment analysis, Scientometrics 76(3): 483-501. http://dx.doi.org/10.1007/s11192-007-1896-4

Simar, L.; Wilson, P. 2003. Efficiency analysis: the statistical approach: lecture notes. Institut de Statistique, UCL, Louvain-la-Neuve.

Tvaronaviciene, M.; Grybaite, V.; Tvaronaviciene, A. 2009. If institutional performance matters: development comparisons of Lithuania, Latvia and Estonia, Journal of Business Economics and Management 10(3): 271-278. http://dx.doi.org/10.3846/1611-1699.2009.10.271-278

Unesco. 2010. Data Centre, Montreal: UNESCO Institute for Statistics, in On-line.

Wang, E. C.; Huang, W. C. 2007. Relative efficiency of R\&D activities: a cross-country study accounting for environmental factors in the DEA approach, Research Policy 36(2): 260-273. http://dx.doi.org/10.1016/j.respol.2006.11.004

World Bank. 2010. World Development Indicators, in On-line.

Zhong, W.; Yuan, W.; Li, S. X., et al. 2011. The performance evaluation of regional R\&D investments in China: an application of DEA based on the first official China economic census data, Omega-International Journal of Management Science 39(4): 447-455.

http://dx.doi.org/10.1016/j.omega.2010.09.004

Aleksander ARISTOVNIK is an Associate Professor in the Department of Public Sector Economics at the Faculty of Administration (University of Ljubljana, Slovenia). His areas of research interest encompass Public Sector Economics, International Economics, International Finance and Economics of the EU. He has actively participated in more than thirty international conferences around the world and published many professional and scientific articles in various domestic and recognized international publications (Eastern European Economics, Journal of Economics, South-Eastern Europe Journal of Economics, Transformations in Business and Economics, etc.), recently. He is also a member of various international associations and organisations (e.g. European Economic Association, Regional Studies Association, INFER). 